\title{
Foreword
}

\section{John Weldon}

THis Is My fourth year as director of the Offset Project. During that time I've had the pleasure of working with dozens of dedicated student editors and together we've published over 200 stories, poems, musical compositions, films, animations and fine art reproductions sourced from well over a thousand submissions.

This once purely literary journal, now embraces the wider creative arts, including within its covers a music CD and a multimedia DVD. The wider Offset umbrella now also incorporates an art exhibition and thanks to a generous grant from The Copyright Agency Limited (CAL) will this year stage a three day creative arts festival at the Footscray Community Arts Centre.

Offset is maturing. From its base in Victoria University's School of Communication and the Arts it has grown, claiming a place for itself in the artistic community of Melbourne's west. It's reaching out to the folk of that region and it's offering them a chance to tell their stories.

In 2011 Offset published a story in Arabic - the journal's first inclusion of works in languages other than English. This year, through the vehicle of the Offset Creative Arts Festival, the project is providing a forum for members of the Ethiopian and Vietnamese communities to celebrate their creative arts heritage.

This is no longer just a journal, but a bridge to the stories, art and music of a region, produced by students who continue to look upwards and outwards beyond the confines of their university.

I write these words as the journal is about to go into layout. The stories, poems and images that will form this year's journal are soon to break free of their bulldog clips, manila folders and desk drawers and will somehow, magically it seems to me, array themselves between the covers of Offset 2012. 
I say magically, even though I know it's not true. A team of talented editors, designers and communicators crafts this journal. It's borne of hard work. Individual pieces are welded, woven and spliced together. They are annealed through heated debate and a desire for excellence. Offset is never an easy journey, but it is always worthwhile.

This year's clutch of stories focuses on the west as a location, as a muse and as an idea. They evoke the sense of otherness that living out west often embodies - no matter where the west may be for you. They lead us through worlds imaginary and arrestingly real. Annie D'Aquino's story is located in a caravan park around the corner from my place in Brooklyn. I have walked the same streets as its characters - i've even eaten from the same kebab shop as they do. Isi Unikowski speaks of men buying grapes 'from the back of lorries in puddled pitted vacant lots'. I see those men every autumn. Others tales embrace worlds unknown, slippery perhaps, hidden, yet I find myself in their clatter and hum too.

This is a wonderful collection of works and a real testament to the editorial team that has put it together. I hope you enjoy finding and losing yourself within these pages as much as I did.

Offset Project Director John Weldon 